\title{
Temperature and salinity effects on strontium incorporation in otoliths of larval spot (Leiostomus xanthurus)
}

\author{
Gretchen Bath Martin, Simon R. Thorrold, and Cynthia M. Jones
}

\begin{abstract}
Temperature dependence of strontium/calcium $(\mathrm{Sr} / \mathrm{Ca})$ ratios in foraminiferal calcite and coral aragonite is well established; however, factors controlling $\mathrm{Sr} / \mathrm{Ca}$ ratios in fish otoliths remain obscure. To assess temperature dependence of $\mathrm{Sr} / \mathrm{Ca}$ in marine fish otoliths, we reared spot (Leiostomus xanthurus) larvae under controlled temperature $\left(17-26^{\circ} \mathrm{C}\right)$ and salinity $(15 \% \circ$ and $25 \%$ ). We found a significant linear relationship between temperature and $\mathrm{Sr} / \mathrm{Ca}$ ratios, with a sensitivity of approximately $5 \% \cdot{ }^{\circ} \mathrm{C}^{-1}$. Otolith $\mathrm{Sr} / \mathrm{Ca}$ values were also significantly higher at a salinity of $25 \%$ vs. $15 \%$, after accounting for differences in dissolved $\mathrm{Sr} / \mathrm{Ca}$ ratios in the ambient water, with a sensitivity of approximately $1 \% /$ salinity $(\% o$ ). These observations complicate the use of $\mathrm{Sr} / \mathrm{Ca}$ ratios to determine temperature histories of spot larvae, because accurate temperature reconstructions are possible only with a priori knowledge of both ambient salinity and dissolved $\mathrm{Sr} / \mathrm{Ca}$ ratios. Fully marine species residing in oceanic waters will not experience significant salinity variations; therefore, otolith $\mathrm{Sr} / \mathrm{Ca}$ ratios may be useful recorders of temperature exposure. Otolith $\mathrm{Sr} / \mathrm{Ca}$ thermometry in coastal fish species that make regular excursions into estuarine waters will be more problematic. Multiple geochemical tracers, including oxygen stable isotopes and other trace elements, may be necessary to accurately reconstruct temperature and salinity histories in these species.
\end{abstract}

Résumé : Il est bien démontré que les rapports strontium/calcium $(\mathrm{Sr} / \mathrm{Ca})$ dans la calcite des foraminifères et l'aragonite des coraux sont dépendants de la température; cependant, les facteurs qui contrôlent les rapports $\mathrm{Sr} / \mathrm{Ca}$ dans les otolithes des poissons restent incertains. Afin d'évaluer le lien entre la température et les rapports $\mathrm{Sr} / \mathrm{Ca}$ dans les otolithes de poissons marins, nous avons élevé des larves du tambour croca (Leiostomus xanthurus) dans des conditions contrôlées de température $\left(17-26^{\circ} \mathrm{C}\right)$ et de salinité $(15 \%$ et $25 \%$ ). Il existe une relation linéaire significative entre la température et les rapports $\mathrm{Sr} / \mathrm{Ca}$, avec une sensibilité d'environ $5 \% /{ }^{\circ} \mathrm{C}$. Les valeurs de $\mathrm{Sr} / \mathrm{Ca}$ sont aussi significativement plus élevées à la salinité de $25 \%$ qu'à $15 \%$, une fois les différences des rapports de $\mathrm{Sr} / \mathrm{Ca}$ dissous dans l'eau ambiante prises en compte, avec une sensibilité d'environ $1 \%$ /salinité (\%o). Ces observations rendent plus complexe l'utilisation des rapports $\mathrm{Sr} / \mathrm{Ca}$ pour reconstituer l'histoire thermique des larves du tambour croca, parce que des reconstitutions précises de la température ne sont possibles que si la salinité ambiante et les rapports de $\mathrm{Sr} / \mathrm{Ca}$ de l'eau sont connus d'avance. Puisque les espèces totalement marines habitant les eaux océaniques ne subissent pas de variations significatives de salinité, les rapports $\mathrm{Sr} / \mathrm{Ca}$ de leurs otolithes peuvent être d'utiles témoins de leur exposition à la température. La thermométrie à l'aide du rapport $\mathrm{Sr} / \mathrm{Ca}$ des otolithes chez les espèces côtières de poissons qui font des incursions régulières dans les eaux saumâtres pose plus de problèmes. L'utilisation de multiples traceurs géochimiques, dont les isotopes stables d'oxygène et d'autres éléments traces, peut s'avérer nécessaire pour arriver à reconstituer l'histoire de l'exposition à la température et à la salinité de ces espèces.

[Traduit par la Rédaction]

\section{Introduction}

Inspired by Odum's (1951a, 1951b) and Turekian's (1964) pioneering work on the biogeochemical cycling of strontium (Sr) in marine environments, scientists have used strontium concentrations of marine-carbonate structures to infer temperatures of present and past marine environments. Stron- tium thermometry based on aragonite in coral skeletons may reveal temperature variation in marine environments over annual to millennial time scales (e.g., Beck et al. 1992; Alibert and McCulloch 1997). Several studies have also suggested that $\mathrm{Sr}$ deposition in the calcite tests of marine foraminifera may be temperature-dependent (e.g., Elderfield et al. 1996; Lea and Martin 1996; Lea et al. 1999). Similarly,

Received 3 February 2003. Accepted 10 September 2003. Published on the NRC Research Press Web site at http://cjfas.nrc.ca on 3 February 2004.

J17321

G.B. Martin ${ }^{\mathbf{1 , 2}}$ and C.M. Jones. Department of Biological Sciences, Old Dominion University, Norfolk, VA 23529, U.S.A.

S.R. Thorrold. Biology Department, Woods Hole Oceanographic Institution, Woods Hole, MA 02543, U.S.A.

${ }^{1}$ Corresponding author (e-mail: Gretchen.Bath.Martin@noaa.gov).

${ }^{2}$ Present address: NOAA, NOS, NCCOS, Center for Coastal Fisheries and Habitat Research, 101 Pivers Island Road, Beaufort, NC 28516, U.S.A. 
strontium/calcium $(\mathrm{Sr} / \mathrm{Ca})$ ratios in aragonite mollusc shells have been used to discern temperature and salinity variability in estuarine environments (Dodd and Crisp 1982; Stecher et al. 1996).

The geochemistry of otolith aragonite may also record temperature and elemental composition of ambient environments (Campana 1999). Otoliths are metabolically inert calcium carbonate structures formed by concentric daily growth increments in teleost fishes (Campana and Neilson 1985; Jones 1986). The chemical composition of otoliths may, in turn, reflect that of the surrounding water (Farrell and Campana 1996; Milton and Chenery 2001), as modified by temperature (Thorrold et al. 1997; Bath et al. 2000). This observation has led to the development of applications using otolith chemistry in conjunction with the chronological properties of otoliths to retrospectively track larval-transport pathways through time (Tzeng and Tsai 1994; Thorrold et al. 1997). Otolith $\mathrm{Sr} / \mathrm{Ca}$ values have also been used to examine transport pathways as a function of ambient temperature (Radtke 1989; Townsend et al. 1989; Gallahar and Kingsford 1996) or salinity (Kalish 1990; Halden et al. 1995; Secor et al. 1995).

Strontium ions have the same valence and a similar ionic radius as calcium ions and are readily incorporated into aragonite by solid substitution for $\mathrm{Ca}$ according to the following equation:

$$
\mathrm{Sr}^{2+}+\mathrm{CaCO}_{3} \rightarrow \mathrm{SrCO}_{3}+\mathrm{Ca}^{2+}
$$

The amount of substitution is a function of the partition coefficient between aragonite and the fluid from which the $\mathrm{Ca}$ and $\mathrm{Sr}$ ions precipitate. In most otolith studies, the partition coefficient is expressed relative to the ambient water because of difficulties in measuring concentrations in the endolymphatic fluid surrounding the otolith (Bath et al. 2000; Milton and Chenery 2001; but see Kalish 1991). Therefore,

$$
[\mathrm{Sr} / \mathrm{Ca}]_{\text {otolith }}=D_{\mathrm{Sr}}[\mathrm{Sr} / \mathrm{Ca}]_{\text {water }}
$$

where $D_{\mathrm{Sr}}$ is the partition or distribution coefficient representing the ratio between the $\mathrm{Sr} / \mathrm{Ca}$ of the calcium carbonate structure and ambient water (Morse and Bender 1990).

Strontium thermometry relies on the observation that the $\mathrm{Sr} / \mathrm{Ca}$ partition coefficient is temperature-dependent. Because biogenic aragonite typically is not in thermodynamic equilibrium, the exact form of the temperature dependence is usually determined empirically. Laboratory and in situ studies have been used to validate the temperature dependence of $D_{\mathrm{Sr}}$ in aragonitic coral skeletons (e.g., Smith et al. 1979; Swart 1979; Shen et al. 1996). However, despite a number of apparently successful validation studies, there remains vigorous debate concerning the degree to which $\mathrm{Sr}$ levels in coral skeletons are affected by temperature compared with biological processes (e.g., presence of algal symbionts (Cohen et al. 2002)).

The relationship between temperature and $\mathrm{Sr} / \mathrm{Ca}$ ratios in fish otoliths is likely to be even more complicated than in coral skeletons because the otolith is isolated from seawater by branchial, intestinal, and endolymphatic membranes. Proposed relationships between $\mathrm{Sr} / \mathrm{Ca}$ and temperature include $\mathrm{Sr} / \mathrm{Ca}$ ratios and temperature being positively correlated (Fowler et al. 1995; Arai et al. 1996), negatively correlated
(Townsend et al. 1992), and uncorrelated (Gallahar and Kingsford 1996). It is not clear if these inconsistencies are a result of interspecific variations in $\mathrm{Sr}$ uptake as a function of temperature or by unspecified methodological artifacts in some or all of the experiments.

In one of the few studies to carefully constrain water chemistry and temperature, Bath et al. (2000) found a positive relationship between $D_{\mathrm{Sr}}$ and temperature. However, their experiment was designed to test the influence of water chemistry on otolith composition and only consisted of two temperature treatments at a constant salinity. The objectives in the present study were to resolve the temperature dependence of the $\mathrm{Sr} / \mathrm{Ca}$ partition coefficient in larval spot (Leistomus xanthurus) and to examine if the partition coefficient was also influenced by ambient salinity. Based on the results of Bath et al. (2000), we hypothesized that $\mathrm{Sr} / \mathrm{Ca}$ ratios in larval spot otoliths were a function of temperature but would not be affected by salinity after appropriate correction for the $\mathrm{Sr} / \mathrm{Ca}$ ratio of the ambient water. If the relation between $\mathrm{Sr} / \mathrm{Ca}$ and temperature is sufficiently predictive, this would allow for reconstruction of temperature histories from individual spot larvae. Such reconstructions could, in turn, provide information on larval-dispersal pathways that would be difficult, if not impossible, to gather using conventional approaches.

\section{Materials and methods}

Spot (Leiostomus xanthurus) were spawned and hatched on 10 December 1999 at the NOAA, National Ocean Service, Center for Coastal Fisheries and Habitat Research in Beaufort, North Carolina. Larvae were reared in a common tank in natural seawater at $34 \%$ salinity for 42 days, at which time they were randomly distributed among 24 acidwashed 20-L high-density polyethylene tanks at a density of 2 fish $\cdot \mathrm{L}^{-1}$. Fish were acclimated to the experimental treatments for a week before initiating the experiment to ensure adequate survival of the experimental fish. The $12 \mathrm{~h}$ light $12 \mathrm{~h}$ dark cycle was controlled for the duration of the experiment. The fish were fed an artificial diet (Golden Pearls, 300-500 and 500-800 $\mu \mathrm{m}$, Brine Shrimp Direct, Inc., Ogden, Utah) twice daily ad libitum.

Experimental tanks were randomly assigned two salinity treatments $(15 \%$ and $25 \%$ o $)$ and four temperature treatments $\left(17,20,23\right.$, and $\left.26^{\circ} \mathrm{C}\right)$. Three replicate tanks were used for each treatment combination (24 tanks in total). Room temperature was maintained at $16{ }^{\circ} \mathrm{C}$, and aquarium heaters were used to regulate temperatures within individual tanks. Artificial seawater (Instant Ocean®; Aquarium Systems Inc., Mentor, Ohio) mixed with deionized water was used to regulate salinity. Water was changed at $50 \%$ volume daily to maintain water quality and salinity.

Water samples from each tank were collected every third day and were filtered through $0.22 \mu \mathrm{m}$ cellulose nitrate membrane filters, acidified with $40 \%$ trace metal grade $\mathrm{HCl}$ to $\mathrm{pH} 2$, and then stored frozen for subsequent analysis. Water temperature, salinity, and $\mathrm{pH}$ were also recorded daily (Table 1). After termination of the experiment, all surviving fish were measured and frozen in individual plastic bags.

Sagittal otolith pairs were removed from the fish and scraped clean with acid-washed glass probes in a class-100 clean 
Table 1. Summary of mean water temperature (Temp., ${ }^{\circ} \mathrm{C}, \pm$ standard error $\left.(\mathrm{SE})\right)$, salinity treatment $\left(\mathrm{Sal} ., \%\right.$ ) $,[\mathrm{Sr}]\left(\mu \mathrm{g} \cdot \mathrm{g}^{-1}, \pm \mathrm{SE}\right),[\mathrm{Ca}]$ $\left(\mu \mathrm{g} \cdot \mathrm{g}^{-1}, \pm \mathrm{SE}\right)$, dissolved $\mathrm{Sr} / \mathrm{Ca}\left([\mathrm{Sr} / \mathrm{Ca}] ; \mathrm{mmol} \cdot \mathrm{mol}^{-1}, \pm \mathrm{SE}\right)$, number of otoliths analyzed $(n)$, mean otolith mass $(\mathrm{OM} ; \mathrm{mg}, \pm \mathrm{SE})$, and somatic growth rate $\left(\mathrm{GR} ; \mathrm{mm} \cdot \mathrm{day}^{-1}, \pm \mathrm{SE}\right)$ within each of the 24 tanks during the course of the experiment.

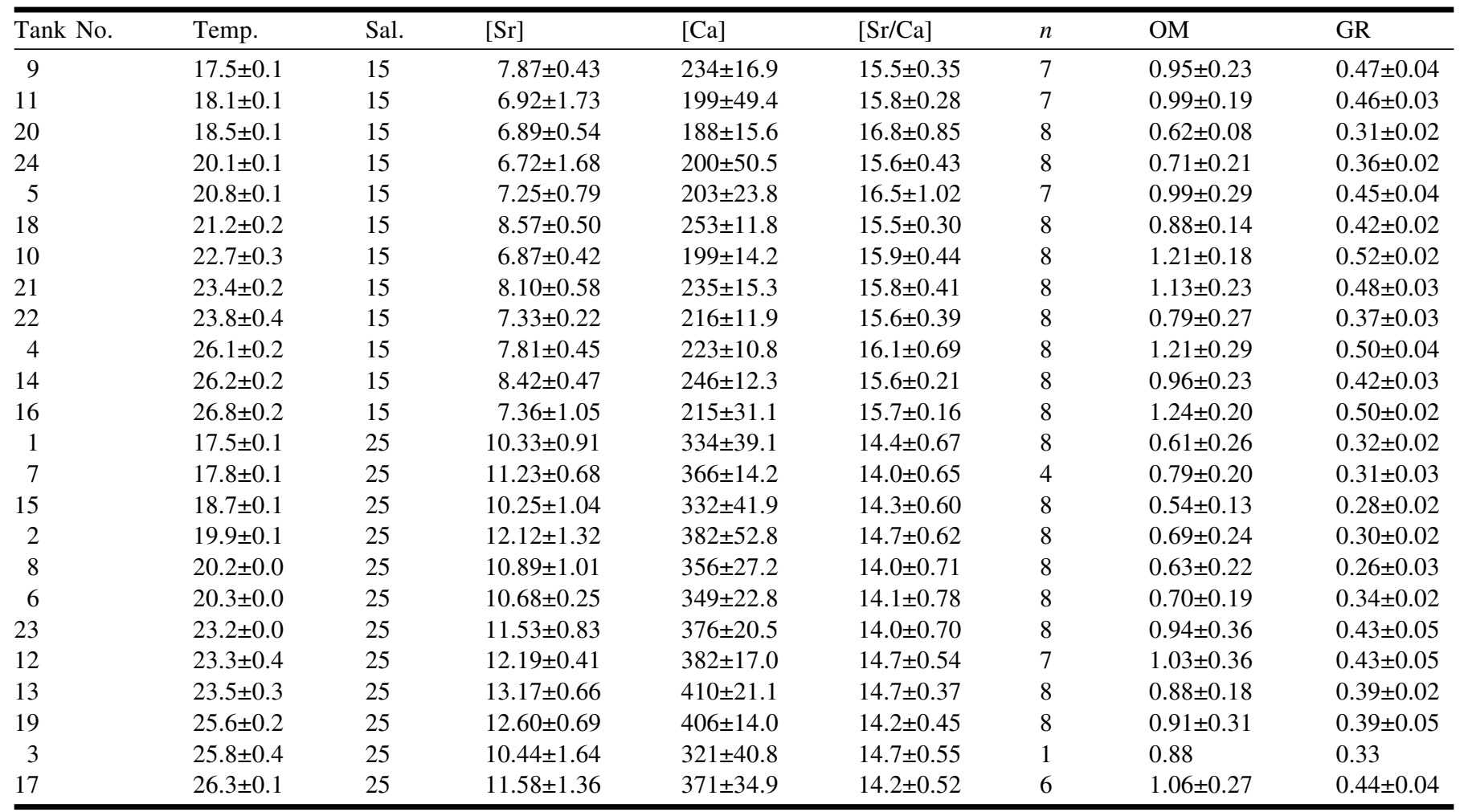

room. Otoliths were ultrasonically cleaned in Milli-Q water (Millipore Corp., Billerica, Mass.) for $7 \mathrm{~min}$ and triple rinsed with ultrapure $\mathrm{H}_{2} \mathrm{O}_{2}$ (Ultrex; J.T. Baker (Mallinckrodt Baker, Inc.), Phillipsburg, N.J.), followed by three sequential rinses of Milli-Q water. Otoliths were then placed on acid-washed glass slides to dry for $36 \mathrm{~h}$ under a class-100 laminar-flow hood. After drying, otoliths were individually weighed to the nearest $10 \mu \mathrm{g}$ and transferred to acid-washed 1.5-mL high-density polyethylene vials.

Otoliths from fish archived at the start of the experiment ( $n=12)$ were also removed and weighed to determine the proportion of otolith material in the experimental fish deposited during the initial larval rearing. Otoliths from two to four fish were pooled for each of three samples to assure adequate masses for analyses, decontaminated, and then assayed using the approach outlined below. The mean $\mathrm{Sr} / \mathrm{Ca}$ ratio from the pooled samples $(n=3)$ of preexperimental otoliths was $3.0 \pm 0.2 \mathrm{mmol} \cdot \mathrm{mol}^{-1}$.

Otoliths from a maximum of eight fish were randomly selected from each tank and prepared for $\mathrm{Sr} / \mathrm{Ca}$ analysis by inductively coupled plasma mass spectrometry (ICP-MS). If the total number of remaining fish in the tank after the experimental period was less than eight, all remaining fish in the tank were used (see Table 1 for fish numbers per tank). Otoliths were dissolved in $70 \%$ ultrapure nitric acid (Ultrex; J.T. Baker) and then diluted to achieve a total dissolved solid concentration of $0.1 \mathrm{mg} \cdot \mathrm{g}^{-1}$ in a $1 \%$ nitric acid solution. Otolith solutions were stored at $4{ }^{\circ} \mathrm{C}$ until the ICP-MS analysis. All analyses were run on a Thermo Finnigan Element 2 ICP-MS (Thermo Electron Corp., Waltham, Mass.) equipped with a self-aspirating $\left(20 \mu \mathrm{L} \cdot \mathrm{min}^{-1}\right)$ PFA nebulizer and a dual-inlet quartz spray chamber. The method measured ${ }^{48} \mathrm{Ca}$ and ${ }^{86} \mathrm{Sr}$ in low resolution $(R=300)$ during a 2 -min acquisition time (a total of 126 passes). Quantification of Sr/Ca ratios followed the procedure outlined by Rosenthal et al. (1999). All samples were standardized to a dissolved solution $\left(0.1 \mathrm{mg} \cdot \mathrm{g}^{-1}\right)$ of an otolith reference powder with a certified $\mathrm{Sr} / \mathrm{Ca}$ ratio of $2.782 \mathrm{mmol} \cdot \mathrm{mol}^{-1}$ (Yoshinaga et al. 2000). The matrix of the standard was therefore matched to the dissolved $\mathrm{Ca}$ levels in the samples. An internal laboratory standard was run after each reference sample to estimate precision of the $\mathrm{Sr} / \mathrm{Ca}$ method. The reference material was then treated as an unknown, and $\mathrm{Sr} / \mathrm{Ca}$ values were determined as for individual samples above. Measured precision (percent relative standard deviation (\% RSD), $n=34$ ) of the $\mathrm{Sr} / \mathrm{Ca}$ method was $0.06 \%$ (Fig. 1).

Analyses of water samples collected during the experiment were also conducted using ICP-MS. Four samples were run from each tank, including the start and end of the experiment and two others at 11-day intervals. All samples were spiked with Indium (In) (to $4.5 \mu \mathrm{g} \cdot \mathrm{g}^{-1}$ ), which was used as an internal standard. The solutions were then aspirated into a Thermo Finnigan Element 2 ICP-MS, via a self-aspirating nebulizer $\left(50 \mu \mathrm{L} \cdot \mathrm{min}^{-1}\right)$ and Scott double-pass spray chamber. Because of the presence of significant interferences on most of the $\mathrm{Ca}$ isotopes, ${ }^{44} \mathrm{Ca},{ }^{88} \mathrm{Sr}$, and ${ }^{115} \mathrm{In}$ were measured in medium resolution (nominal $R=4500$ ). Four samples from each tank were averaged and the mean values were then used in all subsequent analyses. To estimate precision of the water measurements, we determined $\mathrm{Ca}$ and $\mathrm{Sr}$ values 
Fig. 1. Solution-based inductively coupled plasma mass spectrometer (ICP-MS) measurements of $\mathrm{Sr} / \mathrm{Ca}$ values in an otolith certified reference material $\left([\mathrm{Sr} / \mathrm{Ca}]_{\text {ref. std. }}\right)$ plotted in run order through the two days of sample analyses. Overall precision across all runs $(n=34)$ was $0.06 \%$ relative standard deviation (RSD) in the reference material with a certified value of $2.782 \mathrm{mmol} \cdot \mathrm{mol}^{-1}$ (Yoshinaga et al. 2000).

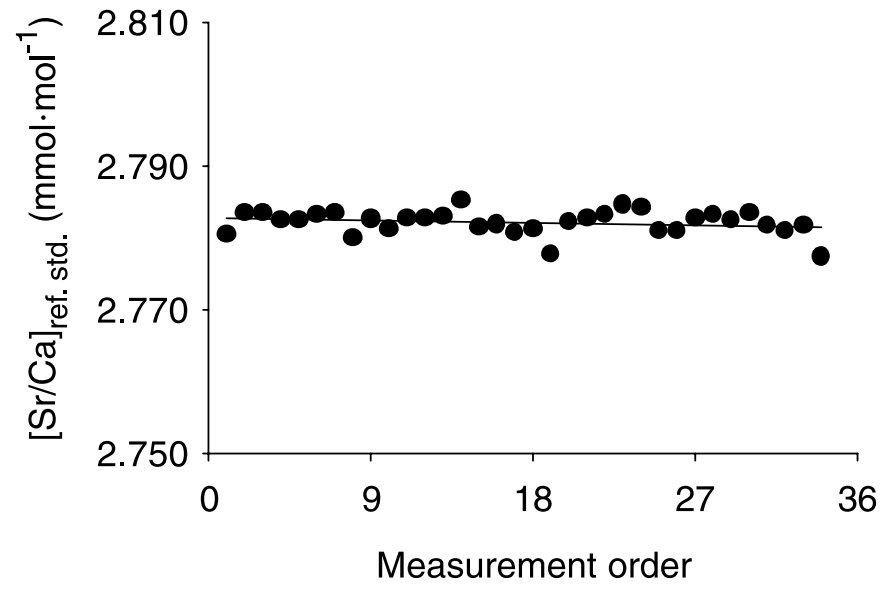

in a seawater reference material (seawater certified reference material (CRM); High Purity Standards, Inc., Charleston, S.C.). Our estimates of precision for both $\mathrm{Ca}$ and $\mathrm{Sr}$ concentrations in the seawater CRM was less than $2 \% \operatorname{RSD}(n=8)$. Partition coefficients $\left(D_{\mathrm{Sr}}\right)$ were calculated by dividing the $\mathrm{Sr} / \mathrm{Ca}$ ratio measured in an otolith by the $\mathrm{Sr} / \mathrm{Ca}$ ratio measured in the treatment tank water. Otolith $\mathrm{Sr} / \mathrm{Ca}$ values from individual fish were averaged within tanks, and then the three tank averages were used as replicates for each of the eight treatments.

Analysis of covariance (ANCOVA) was used to test the influence of otolith precipitation rate on $[\mathrm{Sr} / \mathrm{Ca}]_{\text {otolith }}$. The influence of otolith precipitation rate was also tested by correlating otolith mass with $\mathrm{Sr} / \mathrm{Ca}$ ratios within each of the 23 tanks of sufficient sample sizes. This provided a test of rate effects on $\mathrm{Sr} / \mathrm{Ca}$ ratios because all fish within the tanks have experienced identical environmental conditions (Bath et al. 2000). ANCOVAs were also used to test the influence of somatic growth rate on $[\mathrm{Sr} / \mathrm{Ca}]_{\text {otolith }}$. Finally, the influence of somatic growth rate on otolith precipitation rate was tested by correlating growth rate with $[\mathrm{Sr} / \mathrm{Ca}]_{\text {otolith }}$ within each of the 23 tanks of sufficient sample sizes. Individual growth rates were calculated as the difference between the mean standard length (SL) of pooled fish at the beginning of the experiment and the SL of individual fish at the end of the experiment divided by the number of experiment days. The means of fish growth rates were calculated for individual tanks.

Two-way analysis of variance (ANOVA) was used to test for significant differences in $[\mathrm{Sr} / \mathrm{Ca}]_{\text {otolith }}$ and $D_{\mathrm{Sr}}$ among temperature and salinity treatments. Salinity and temperature were treated as independent categorical variables, and $[\mathrm{Sr} / \mathrm{Ca}]_{\text {otolith }}$ and $D_{\mathrm{Sr}}$ were treated as dependent variables in the analyses. The assumptions of ANOVA were met: residuals were normally distributed and homogeneous among factor levels. Finally, because temperature was a quantitative variable, we were able to test the significance of the relation between both $[\mathrm{Sr} / \mathrm{Ca}]_{\text {otolith }}$ and $D_{\mathrm{Sr}}$ with temperature using both linear and quadratic functions.

\section{Results}

We determined that conditions during the initial rearing period had little effect on the resultant otolith chemistry of the experimental fish because otoliths from these fish averaged less than $50 \mu \mathrm{g}$ compared with a mean value of $890 \mu \mathrm{g}$ for otoliths from fish at the end of the experiment. The $\mathrm{Sr} / \mathrm{Ca}$ ratios of otoliths from 175 juvenile $L$. xanthurus ranged from 3.05 to $6.08 \mathrm{mmol} \cdot \mathrm{mol}^{-1}$, with an overall mean of $4.40 \mathrm{mmol} \cdot \mathrm{mol}^{-1}$. Water $\mathrm{Sr} / \mathrm{Ca}$ values ranged from 11.91 to $19.36 \mathrm{mmol} \cdot \mathrm{mol}^{-1}$, with an overall mean of $15.09 \mathrm{mmol} \cdot \mathrm{mol}^{-1}$. $\mathrm{Sr} / \mathrm{Ca}$ partition coefficients ranged from 0.20 to 0.43 , with an overall mean of 0.29 .

\section{Biomineralization and growth rate effects}

Using otolith mass as a proxy for aragonite precipitation rates, an ANCOVA demonstrated no significant effect of mean otolith mass among tanks on $[\mathrm{Sr} / \mathrm{Ca}]_{\text {otolith }}(F=0.021$, $p>0.05, n=24)$. There was, however, significant variability in $[\mathrm{Sr} / \mathrm{Ca}]_{\text {otolith }}$ among tanks that were functions of temperature and salinity treatments and considerable variations in otolith mass among individual fish within tanks (Table 1). Because individual fish within a tank had experienced identical conditions, we also ran Pearson correlations between otolith mass and otolith $\mathrm{Sr} / \mathrm{Ca}$ within each of 23 tanks. A total of 14 of 23 correlations were negative, but only three of 23 correlations were significant after Bonferroni correction for multiple tests. Somatic growth rates were, as expected, significantly affected by tank temperature $(F=4.52, p<$ $0.05, n=24)$ and tank salinity $(F=11.43, p<0.05, n=24)$. An ANCOVA also demonstrated no significant effect of mean growth rates among tanks on $[\mathrm{Sr} / \mathrm{Ca}]_{\text {otolith }}(F=0.016, p>$ $0.05, n=24)$. Looking at the relation within tanks, Pearson correlations between growth rate and $[\mathrm{Sr} / \mathrm{Ca}]_{\text {otolith }}$ demonstrated that although 16 of 23 correlations were negative, only two of 23 correlations were significant after Bonferroni adjustment.

\section{Water chemistry}

Elemental concentrations of ambient water in the tanks were significantly different between salinity treatments (Fig. 2). As expected, both $\mathrm{Ca}$ and $\mathrm{Sr}$ were higher at $25 \% 0$ than at $15 \%$ o $\left([\mathrm{Ca}]_{\text {water }},|t|_{0.05,(2), 22}=14.62, p<0.05 ;[\mathrm{Sr}]_{\text {water }}\right.$, $\left.\left.|t|\right|_{0.05,(2), 22}=11.85, p<0.05\right)$. Water $\mathrm{Sr} / \mathrm{Ca}$ ratios did not vary among temperature treatments but were significantly different between salinity treatments $\left([\mathrm{Sr} / \mathrm{Ca}]_{\text {water }},|t|_{0.05,(2), 22}=\right.$ 10.41, $p<0.05)$. Proportionately lower $\mathrm{Ca}$ concentrations relative to dissolved $\mathrm{Sr}$ in $15 \%$ o salinity tanks led to higher $\mathrm{Sr} / \mathrm{Ca}$ ratios in the low salinity treatment (Table 1; Fig. 2), presumably because $\mathrm{Sr} / \mathrm{Ca}$ ratios were higher in the deionized water source than in the $25 \%$ o salinity artificial seawater.

\section{Otolith [Sr/Ca]}

The two-way ANOVA model found a significant salinity and temperature effect on $[\mathrm{Sr} / \mathrm{Ca}]_{\text {otolith }}$ (Table 2). The interaction term was not significant (Table 2). A post-hoc Tukey multiple comparison showed significant differences among 
Fig. 2. Measured tank water (a) Ca and (b) Sr concentrations $\left(\mu \mathrm{g} \cdot \mathrm{g}^{-1}, \pm\right.$ standard error (SE)) by sample date for the duration of the experiment. (c) The calculated $\mathrm{Sr} / \mathrm{Ca}$ ratio $\left(\mathrm{mmol} \cdot \mathrm{mol}^{-1}\right)$ in these water samples. The solid symbols represent the $25 \%$ salinity treatment tanks, and the open symbols represent the $15 \%$ o salinity treatment tanks. Each of the four temperature treatments is represented by a different symbol shape: $17{ }^{\circ} \mathrm{C}$ (circles), $20{ }^{\circ} \mathrm{C}$ (triangles), $23{ }^{\circ} \mathrm{C}$ (squares), and $26{ }^{\circ} \mathrm{C}$ (diamonds).
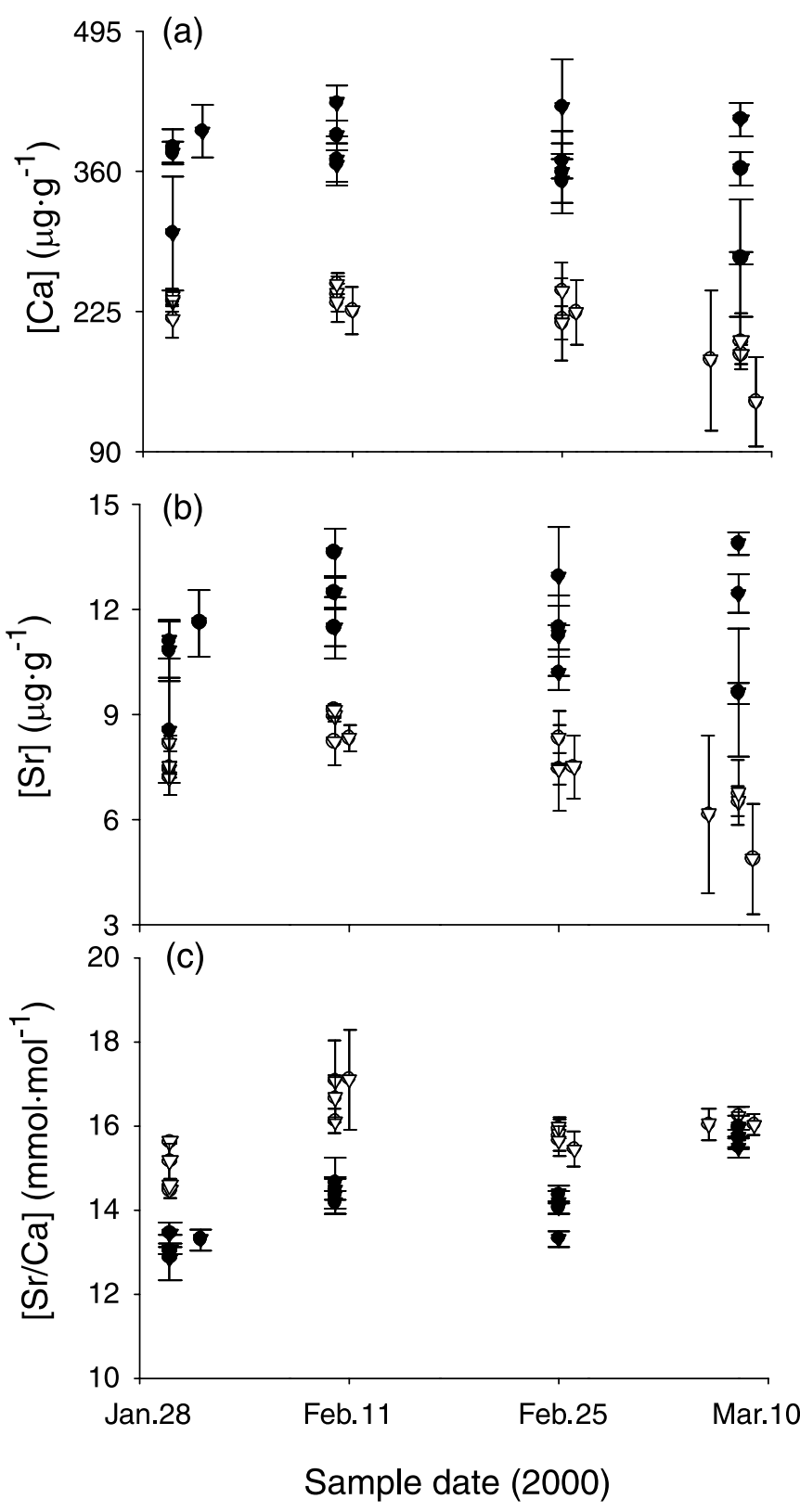

all temperature treatments. There was also a significant linear, but not quadratic, relation between $[\mathrm{Sr} / \mathrm{Ca}]_{\mathrm{otolith}}$ and temperature (Table 2; Fig. 3). At 25\%o salinity, the linear leastsquares regression equation between $[\mathrm{Sr} / \mathrm{Ca}]_{\text {otolith }}$ and temperature $\left(r^{2}=0.95, n=12\right)$ was

$$
\begin{aligned}
& {[\mathrm{Sr} / \mathrm{Ca}]_{\text {otolith }}=0.154 \pm 0.012\left(T\left({ }^{\circ} \mathrm{C}\right)\right)} \\
& +1.16 \pm 0.256(95 \% \text { confidence interval })
\end{aligned}
$$

For $15 \%$ o salinity, the linear equation $\left(r^{2}=0.92, n=12\right)$ was

$$
\begin{aligned}
& {[\mathrm{Sr} / \mathrm{Ca}]_{\text {otolith }}=0.179 \pm 0.017\left(T\left({ }^{\circ} \mathrm{C}\right)\right)} \\
& +0.348 \pm 0.382(95 \% \text { confidence interval })
\end{aligned}
$$

\section{Sr/Ca partition coefficients}

We detected significant salinity and temperature effects on $\mathrm{Sr} / \mathrm{Ca}$ partition coefficients (Table 2), with a nonsignificant interaction between the two factors (Table 2). The linear function between $D_{\mathrm{Sr}}$ and temperature was significant, but the quadratic function was not (Table 2; Fig. 4). For 25\% salinity, the linear least-squares regression equation between $D_{\mathrm{Sr}}$ and temperature $\left(r^{2}=0.90, n=12\right)$ was

$$
\begin{aligned}
D_{\mathrm{Sr}}= & 0.010 \pm 0.001\left(T\left({ }^{\circ} \mathrm{C}\right)\right) \\
& +0.088 \pm 0.025(95 \% \text { confidence interval })
\end{aligned}
$$

For $15 \%$ salinity, the linear equation $\left(r^{2}=0.91, n=12\right)$ was

$$
\begin{aligned}
D_{\mathrm{Sr}}= & 0.012 \pm 0.001\left(T\left({ }^{\circ} \mathrm{C}\right)\right) \\
& +0.013 \pm 0.026(95 \% \text { confidence interval })
\end{aligned}
$$

\section{Discussion}

Both $[\mathrm{Sr} / \mathrm{Ca}]_{\text {otolith }}$ and $\mathrm{Sr} / \mathrm{Ca}$ partition coefficients increased linearly as a function of temperature over the ranges analyzed $\left(17-26^{\circ} \mathrm{C}\right)$. The temperature effect was not a result of differences in water chemistry among temperature treatments, as elemental concentrations and $\mathrm{Sr} / \mathrm{Ca}$ ratios did not differ among temperature treatments. Presumably, there was no effect of diet, as all fish were fed the same food. Moreover, several experimental studies have found little evidence for an effect of diet on otolith Sr incorporation (Hoff and Fuiman 1995; Farrell and Campana 1996; Milton and Chenery 2001). We cannot eliminate physiological differences when such differences are correlated with growth because there was a significant effect of temperature on growth rate. However, aragonite precipitation rates and larval growth rates within individual tanks were in most cases not significantly correlated with $\mathrm{Sr} / \mathrm{Ca}$ ratios in otoliths. Temperature was therefore the dominant variable controlling $\mathrm{Sr} / \mathrm{Ca}$ ratios in the otoliths of larval spot in our experiment.

Bath et al. (2000) provided a first-order approximation of the temperature partition coefficient relation for larval spot, L. xanthurus $(18-32.6 \mathrm{~mm} \mathrm{SL}$, mean $=24.2 \mathrm{~mm} \mathrm{SL})$ :

$$
D_{\mathrm{Sr}}=0.0046\left(T\left({ }^{\circ} \mathrm{C}\right)+0.089 \quad\left(r^{2}=0.62\right)\right.
$$

Two points are worth noting with respect to the results of our earlier study. First, Bath et al. (2000) reported Sr/Ca partition coefficients that were significantly lower at a given temperature $\left(0.18\right.$ at $20{ }^{\circ} \mathrm{C}, 20 \%$ ) than what we found in the present study $\left(0.26\right.$ at $20{ }^{\circ} \mathrm{C}, 15 \%$; 0.30 at $20{ }^{\circ} \mathrm{C}, 25 \%$ ). The intercept of the linear regression between $D_{\mathrm{Sr}}$ and temperature (for the 20 and $25^{\circ} \mathrm{C}$ treatments) was statistically indistinguishable between the two experiments. However, the temperature sensitivity of the relation between $D_{\mathrm{Sr}}$ and temperature in the present study $\left(\sim 5 \% \cdot{ }^{\circ} \mathrm{C}^{-1}\right)$ was approximately twice that reported by Bath et al. (2000) $\left(\sim 2 \% \cdot{ }^{\circ} \mathrm{C}^{-1}\right)$. Larvae were reared at two temperatures in the earlier study (20 and $25{ }^{\circ} \mathrm{C}$ ). It is possible, therefore, that Bath et al. (2000) underestimated the temperature dependence because of a lack of temperature treatments. It is more difficult to reconcile the different estimates of $D_{\mathrm{Sr}}$ between the two 
Table 2. Leiostomus xanthurus. Analysis of variance (ANOVA) table summarizing the effect of salinity and temperature treatments on otolith $[\mathrm{Sr} / \mathrm{Ca}]$ and the $\mathrm{Sr}$ distribution coefficient $\left(D_{\mathrm{Sr}}\right)$, along with significance tests of linear and quadratic contrasts between temperature and otolith $[\mathrm{Sr} / \mathrm{Ca}]$ and temperature and $D_{\mathrm{Sr}}$.

\begin{tabular}{|c|c|c|c|c|c|}
\hline Source & SS & $\mathrm{df}$ & MS & $F$ & $p<F$ \\
\hline \multicolumn{6}{|l|}{ Otolith $[\mathrm{Sr} / \mathrm{Ca}]$} \\
\hline Salinity & 0.241 & 1 & 0.241 & 7.42 & 0.015 \\
\hline Temp & 6.20 & 3 & 2.1 & 63.6 & $<0.001$ \\
\hline Salinity $\times$ temperature & 0.068 & 3 & 0.023 & 0.695 & 0.569 \\
\hline Error & 0.520 & 16 & 0.032 & & \\
\hline Linear & 5.98 & 1 & 5.98 & 184 & $<0.0001$ \\
\hline Quadratic & 0.047 & 1 & 0.047 & 1.46 & 0.245 \\
\hline \multicolumn{6}{|l|}{$D_{\mathrm{Sr}}$} \\
\hline Salinity & 0.011 & 1 & 0.011 & 61.8 & $<0.0001$ \\
\hline Temperature & 0.027 & 3 & 0.009 & 52.2 & $<0.0001$ \\
\hline Salinity $\times$ temperature & 0.0004 & 3 & 0.000 & 0.78 & 0.524 \\
\hline Error & 0.003 & 16 & 0.000 & & \\
\hline Linear & 0.026 & 1 & 0.026 & 151 & $<0.0001$ \\
\hline Quadratic & 0.0002 & 1 & 0.0002 & 1.17 & 0.295 \\
\hline
\end{tabular}

Note: SS, sums of squares; df, degrees of freedom; MS, mean squares.

Fig. 3. $\mathrm{Sr} / \mathrm{Ca}\left(\mathrm{mmol} \cdot \mathrm{mol}^{-1}\right)$ ratios in otoliths of laboratory-reared Leiostomus xanthurus as a function of tank temperatures $\left({ }^{\circ} \mathrm{C}\right)$ at two salinity levels: $15 \% \circ(\bigcirc)$ and $25 \%$ (O). The lines were fitted by linear least-squares regression for each of the salinity treatments.

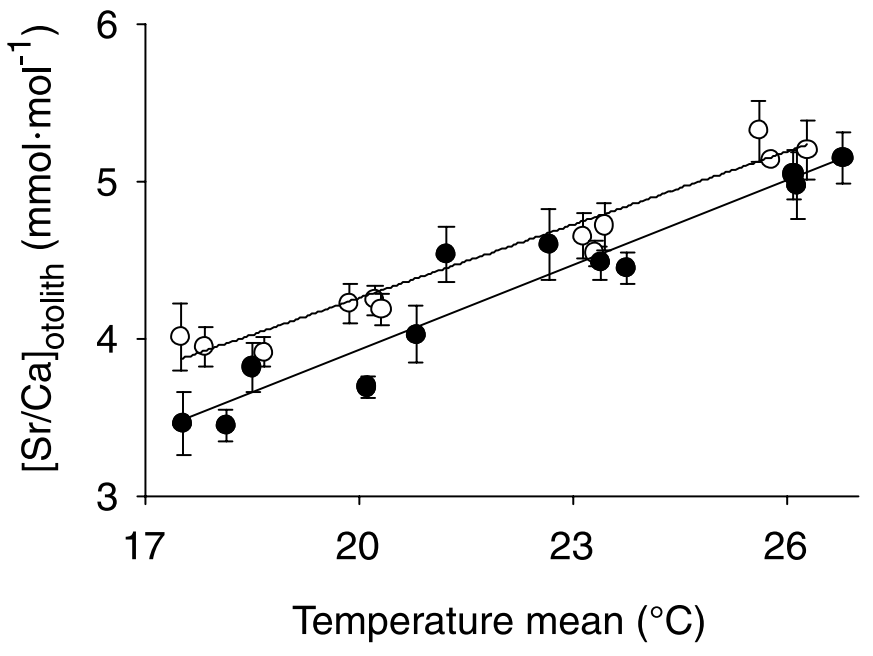

studies because both were based on multiple treatments with adequate levels of replication. We conclude that there are other factors influencing the magnitude of $D_{\mathrm{Sr}}$ in the otoliths of larval spot that remain to be identified.

The effect of temperature on $\mathrm{Sr} / \mathrm{Ca}$ ratios in the otoliths of other fish species is ambiguous. Several studies have also shown positive effects of temperature on $\mathrm{Sr}$ incorporation into otoliths (Kalish 1989; Limburg 1995; Arai et al. 1996). Other researchers have suggested an inverse correlation between temperature and Sr/Ca ratios in otoliths (Radtke 1989; Sadovy and Severin 1992; Secor et al. 1995) or have been unable to detect any temperature dependence of $[\mathrm{Sr} / \mathrm{Ca}]_{\text {otolith }}$ (Gallahar and Kingsford 1996; Tzeng 1996; Chesney et al. 1998). Methodological problems may be responsible for at least some of these discrepancies, as few studies have adequately constrained $[\mathrm{Sr} / \mathrm{Ca}]_{\text {water }}$ The choice of analytical in-
Fig. 4. Sr/Ca partition coefficients $\left(D_{\mathrm{Sr}}\right)$ for otoliths of laboratoryreared Leiostomus xanthurus as a function of tank temperatures $\left({ }^{\circ} \mathrm{C}\right)$ at two salinity levels: $15 \% \circ(\bigcirc)$ and $25 \%$ ( $\left.\bigcirc\right)$. The lines were fitted by linear least-squares regression for each of the salinity treatments.

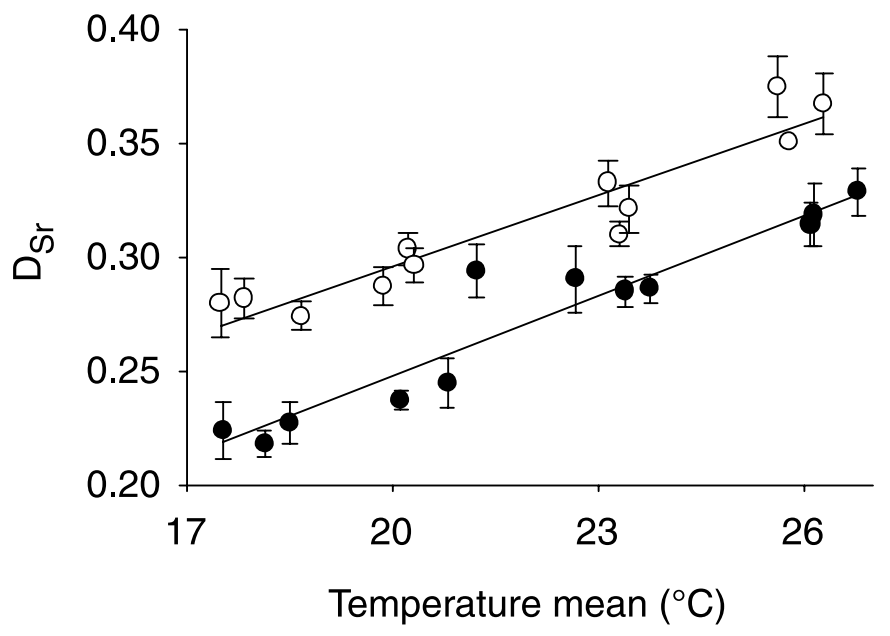

strumentation may also be a factor, as most studies have used electron probe microanalysis (EPMA). The application of $\mathrm{Sr} / \mathrm{Ca}$ thermometry, at least in coral skeletons, generally requires instrument precision of better than $0.5 \%$ RSD (Lea and Martin 1996). However, instrument uncertainty of $\mathrm{Sr} / \mathrm{Ca}$ measurements in otoliths using EPMA is typically on the order of 5-10\% (RSD) (e.g., Gunn et al. 1992; Campana et al. 1997). Precision of the Sr/Ca method using sector-field ICPMS that we employed was $0.06 \%$ RSD, matching the best precision reported for instruments routinely used to determine $\mathrm{Sr} / \mathrm{Ca}$ ratios in biogenic carbonates (Rosenthal et al. 1999; Schrag 1999). The increased precision of our estimates over earlier probe-based methods certainly increased our ability to detect relatively subtle, but predictable, effects of temperature on $\mathrm{Sr} / \mathrm{Ca}$ ratios. We suspect that developmental stage may also influence Sr/Ca in otoliths. Kalish (1990) 
suggested that variations in Ca-binding proteins caused by changes in reproductive status influenced $\mathrm{Sr} / \mathrm{Ca}$ ratios in otoliths of adult fish. Such regulation may then be less important in the larval stages that we examined compared with studies on older life history stages. Finally, it is likely that $\mathrm{Sr}$ and $\mathrm{Ca}$ uptake in otoliths is species-specific, and therefore a single relationship between $\mathrm{Sr} / \mathrm{Ca}$ and temperature may not apply to all marine fish species.

Considerable debate also surrounds the temperature dependence of $\mathrm{Sr} / \mathrm{Ca}$ partition coefficients in other biogenic carbonates. Most work has been conducted on the aragonite skeletons of hermatypic corals that typically demonstrate an inverse relation between $D_{\mathrm{Sr}}$ and temperature (Smith et al. 1979; Beck et al. 1992; Sinclair et al. 1998). Positive correlations have been identified between $D_{\mathrm{Sr}}$ and temperature in molluscs (Buchardt and Fritz 1978; Klein et al. 1996; Vander Putten et al. 2000) and calcitic foraminifera (Elderfield et al. 1996; Lea et al. 1999). Interestingly, $\mathrm{Sr} / \mathrm{Ca}$ ratios of the aragonite from studies that documented a positive relation between $D_{\mathrm{Sr}}$ and temperature were considerably lower $\left(<2.5 \mathrm{mmol} \cdot \mathrm{mol}^{-1}\right)$ than that found in coral or sclerosponge aragonite $\left(8-10 \mathrm{mmol} \cdot \mathrm{mol}^{-1}\right)$. There may, therefore, be fundamentally different mechanisms generating the temperature dependence of $\mathrm{Sr} / \mathrm{Ca}$ ratios between low $\mathrm{Sr}$ and high $\mathrm{Sr}$ aragonite. Stecher et al. (1996) and Purton et al. (1999) suggested that metabolic effects correlated with temperature led to positive correlations between $\mathrm{Sr} / \mathrm{Ca}$ and temperature in bivalve and gastropod shells. We have been consistently unable to find correlations between otolith $\mathrm{Sr} / \mathrm{Ca}$ and several proxies of metabolic rate (somatic and otolith growth) in individual spot larvae. Clearly more work in this area is needed, although we believe that there is now sufficient evidence to reject analogies between the temperature dependence of $D_{\mathrm{Sr}}$ in coral skeletons and fish otoliths.

More $\mathrm{Sr}$ was incorporated into larval spot otoliths at salinities of $25 \%$ o than at $15 \%$, after accounting for differences in the $\mathrm{Sr} / \mathrm{Ca}$ ratios of the rearing water. Dietary effects were unlikely to have caused the differences, following the argument outlined above for temperature. Rather, absolute $\mathrm{Sr}$ levels appeared to influence otolith $\mathrm{Sr} / \mathrm{Ca}$ values beyond that predicted by $[\mathrm{Sr} / \mathrm{Ca}]_{\text {water }}$ Recent studies by Chowdhury and Blust $(2001,2002)$ provide a potential mechanism for our observations. They found that dissolved $\mathrm{Ca}$ and $\mathrm{Sr}$ in freshwater carp mutually inhibited uptake of ions across branchial and intestinal membranes. Positive, nonlinear inhibition of $\mathrm{Ca}$ ions by $\mathrm{Sr}$ ions at uptake sites on these membranes would, in turn, result in the observed effect of dissolved $\mathrm{Sr}$ on $\mathrm{Sr} / \mathrm{Ca}$ ratios in otoliths.

The observation that $\mathrm{Sr} / \mathrm{Ca}$ ratios in otoliths depend on temperature, $[\mathrm{Sr} / \mathrm{Ca}]_{\text {water }}$, and $[\mathrm{Sr}]_{\text {water }}$ raises a number of potential problems for fish $\mathrm{Sr}$ thermometry. Both $[\mathrm{Sr} / \mathrm{Ca}]_{\text {water }}$ and $[\mathrm{Sr}]_{\text {water }}$ must be constrained before temperature can be estimated from otolith $\mathrm{Sr} / \mathrm{Ca}$. Because $\mathrm{Sr}$ and $\mathrm{Ca}$ have long ( $\sim 10^{6}$ years) residence times in the world's oceans, fish that spend their entire lives in shelf or oceanic water masses will not experience significant variations in either $[\mathrm{Sr}]_{\text {water }}$ or $[\mathrm{Sr} / \mathrm{Ca}]_{\text {water }}$ However, many fish species living in coastal waters are estuarine-dependent and traverse waters of variable water chemistry and temperature. Reconstruction of temperature histories will therefore require independent estimates of $[\mathrm{Sr}]_{\text {water }}$ and $[\mathrm{Sr} / \mathrm{Ca}]_{\text {water }}$. Temperature and salinity are easy to measure and are frequently incorporated in sampling designs. Water strontium and calcium concentrations are rarely measured yet seem to be critical for the application of strontium thermometry to field-collected fish.

In summary, $\mathrm{Sr} / \mathrm{Ca}$ ratios in the otoliths of larval spot are determined primarily by the physicochemical properties of the ambient water. When combined with the results of our earlier study (Bath et al. 2000), we conclude that temperature, $[\mathrm{Sr} / \mathrm{Ca}]_{\text {water }}$, and $[\mathrm{Sr}]_{\mathrm{water}}$ all have significant effects on otolith $\mathrm{Sr} / \mathrm{Ca}$ ratios. In contrast, we saw no consistent evidence for metabolic effects on $\mathrm{Sr} / \mathrm{Ca}$ ratios in otoliths, at least to the extent that metabolic rates are correlated with individual growth rates. Unfortunately, this does not mean that otolith $\mathrm{Sr} / \mathrm{Ca}$ thermometry will be easy in estuarine-dependent fish species because independent geochemical tracers that constrain both $[\mathrm{Sr} / \mathrm{Ca}]_{\text {water }}$ and $[\mathrm{Sr}]_{\text {water }}$ will need to be developed. For instance, both stable oxygen $\left({ }^{18} \mathrm{O} /{ }^{16} \mathrm{O}\right)$ and strontium $\left({ }^{87} \mathrm{Sr} /{ }^{86} \mathrm{Sr}\right)$ isotopes vary linearly with $[\mathrm{Sr}]_{\text {water }}$ and $[\mathrm{Ca}]_{\text {water }}$ in estuarine systems (Chesney et al. 1998; Thorrold et al. 1998). We suggest, however, that marine fishes that do not experience significant variations in $[\mathrm{Sr}]_{\mathrm{water}}$ and $[\mathrm{Ca}]_{\mathrm{water}}$ are logical species to test our ability to reconstruct temperature histories from $\mathrm{Sr} / \mathrm{Ca}$ ratios in otoliths.

\section{Acknowledgements}

This research was supported by grants from the National Science Foundation to S.R.T. (OCE-0134998) and to S.R.T. and C.M.J. (OCE-9876565), a grant in aid to G.B.M. from the International Women's Fishing Association, and a PEO International Women's Organization Scholar Award to G.B.M. We thank Dr. Zhongxing Chen (LITER, Old Dominion University) for assisting with the water samples and John Burke, Gary Fisher, and Peter Crumley (NOAA, National Ocean Service, CCFHR, Beaufort, N.C.) for their technical support. We also thank Jon Hare, Mark Wuenschel, Erik Williams, Kevin Piner, Dayanand Naik, and Bill Resetarits for comments on earlier drafts of the manuscript. Two anonymous reviewers helped improve the final version of this manuscript.

\section{References}

Alibert, C., and McCulloch, M.T. 1997. Strontium/calcium ratios in modern Porites corals from the Great Barrier Reef as a proxy for sea surface temperature: calibration of the thermometer and monitoring of ENSO. Paleoceanography, 12: 345-363.

Arai, N., Sakamoto, W., and Maeda, K. 1996. Correlation between ambient seawater temperature and strontium-calcium concentration ratios in otoliths of red sea bream Pagurus major. Fish. Sci. 62: 652-653.

Bath, G.E., Thorrold, S.R., Jones, C.M., Campana, S.E., McLaren, J.W., and Lam, J.W.H. 2000. Strontium and barium uptake in aragonitic otoliths of marine fish. Geochim. Cosmochim. Acta, 64: 1705-1714.

Beck, J.W., Edwards, R.L., Ito, E., Taylor, F.W., Recy, J., Rougerie, F., Joannot, P., and Henin, C. 1992. Sea-surface temperature from coral skeletal strontium/calcium ratios. Science (Wash., D.C.), 257: 644-647.

Buchardt, B., and Fritz, P. 1978. Strontium uptake in shell aragonite from the freshwater gastropod Limnaea stagnalis. Science (Wash., D.C.), 199: 291-292. 
Campana, S.E. 1999. Chemistry and composition of fish otoliths: pathways, mechanisms, and applications. Mar. Ecol. Prog. Ser. 188: $263-297$.

Campana, S.E., and Neilson, J.D. 1985. Microstructure of fish otoliths. Can. J. Fish. Aquat. Sci. 42: 1014-1032.

Campana, S.E., Thorrold, S.R., Jones, C.M., Günther, D., Tubrett, M., Longerich, H., Jackson, S., Halden, N.M., Kalish, J.M., Piccoli, P., de Pontual, H., Troadec, H., Panfili, J., Secor, D.H., Severin, K.P., Sale, S.H., Thresher, R., Teesdale, W.J., and Campbell, J.L. 1997. Comparison of accuracy, precision, and sensitivity in elemental assays of fish otoliths using the electron microprobe, proton-induced $\mathrm{X}$-ray emission and laser ablation inductively coupled plasma mass spectrometry. Can. J. Fish. Aquat. Sci. 54: 2068-2079.

Chesney, E.J., McKee, B.M., Blanchard, T., and Chan, L.-H. 1998. Chemistry of otoliths from juvenile menhaden Brevoortia patronus: evaluating strontium, strontium:calcium and strontium isotope ratios as environmental indicators. Mar. Ecol. Prog. Ser. 171: 261273.

Chowdhury, M.J., and Blust, R. 2001. A mechanistic model for the uptake of waterborne strontium in the common carp (Cyprinus carpio L.). Environ. Sci. Technol. 35: 669-675.

Chowdhury, M.J., and Blust, R. 2002. Bioavailability of waterborne strontium to the common carp, Cyprinus carpio, in complexing environments. Aquat. Toxicol. 58: 215-227.

Cohen, A.L., Owens, K.E., Layne, G.D., and Shimizu, N. 2002. The effect of algal symbionts on the accuracy of Sr/Ca paleotemperatures from coral. Science (Wash., D.C.), 296: 331-333.

Dodd, J.R., and Crisp, E.L. 1982. Non-linear variation with salinity of $\mathrm{Sr} / \mathrm{Ca}$ and $\mathrm{Mg} / \mathrm{Ca}$ ratios in water and aragonitic bivalve shells and implications for paleosalinity studies. Palaeogeogr. Palaeoclim. Palaeoecol. 38: 45-56.

Elderfield, H., Bertram, C.J., and Erez, J. 1996. A biomineralization model for the incorporation of trace elements into foraminiferal calcium carbonate. Earth Planet. Sci. Lett. 142: 409-423.

Farrell, J., and Campana, S.E. 1996. Regulation of calcium and strontium deposition on the otoliths of juvenile tilapia, Oreochromis niloticus. Comp. Biochem. Physiol. A, 115: 103-109.

Fowler, A.J., Campana, S.E., Jones, C.M., and Thorrold, S.R. 1995. Experimental assessment of the effect of temperature and salinity on elemental composition of otoliths using solution-based ICPMS. Can. J. Fish. Aquat. Sci. 52: 1421-1430.

Gallahar, N.K., and Kingsford, M.J. 1996. Factors influencing Sr/Ca ratios in otoliths of Girella elevata: an experimental investigation. J. Fish Biol. 48: 174-186.

Gunn, J.S., Harrowfield, I.R., Proctor, C.H., and Thresher, R.E. 1992. Electron probe microanalysis of fish otoliths - evaluation of techniques for studying age and stock discrimination. J. Exp. Mar. Biol. Ecol. 158: 1-36.

Halden, N.M., Babaluk, J.A., Campbell, J.L., and Teesdale, W.J. 1995. Scanning proton microprobe analysis of strontium in an arctic charr, Salvelinus alpinus, otolith: implications for the interpretation of anadromy. Environ. Biol. Fishes, 43: 333-339.

Hoff, G.R., and Fuiman, L.A. 1995. Environmentally induced variation in elemental composition of red drum (Sciaenops ocellatus) otoliths. Bull. Mar. Sci. 56: 578-591.

Jones, C.M. 1986. Determining age of larval fish with the otolith increment technique. Fish. Bull. 84: 91-103.

Kalish, J.M. 1989. Otolith microchemistry: validation of the effects of physiology, age, and environment on otolith composition. J. Exp. Mar. Biol. Ecol. 132: 151-178.

Kalish, J.M. 1990. Use of otolith microchemistry to distinguish the progeny of sympatric anadromous and non-anadromous salmonids. Fish. Bull. 88: 657-666.
Kalish, J.M. 1991. Determinants of otolith chemistry: seasonal variation in the composition of blood plasma, endolymph and otoliths of bearded rock cod Pseudophycis barbatus. Mar. Ecol. Prog. Ser. 74: $137-159$.

Klein, R.T., Lohmann, K.C., and Thayer, C.W. 1996. Sr/Ca and ${ }^{13} \mathrm{C} /{ }^{12} \mathrm{C}$ ratios in skeletal calcite of Mytilus trossulus: covariation with metabolic rate, salinity, and carbon isotopic composition of seawater. Geochim. Cosmochim. Acta, 60: 4207-4221.

Lea, D.W., and Martin, P.A. 1996. A rapid mass spectrometric method for the simultaneous analysis of barium, cadmium, and strontium in foraminiferal shells. Geochim. Cosmochim. Acta, 60: $3143-3149$.

Lea, D.W., Mashiotta, T.A., and Spero, H.J. 1999. Controls on magnesium and strontium uptake in planktonic foraminifera determined by live culturing. Geochim. Cosmochim. Acta, 63: 23692379.

Limburg, K.E. 1995. Otolith strontium traces environmental history of subyearling American shad Alosa sapidissima. Mar. Ecol. Prog. Ser. 119: 25-35.

Milton, D.A., and Chenery, S.R. 2001. Sources and uptake of trace metals in otoliths of juvenile barramundi (Lates calcarifer). J. Exp. Mar. Biol. Ecol. 264: 47-65.

Morse, J.W., and Bender, M.L. 1990. Partition coefficients in calcite - examination of factors influencing the validity of experimental results and their application to natural systems. Chem. Geol. 82: 265-277.

Odum, H.T. 1951a. Notes on the strontium content of sea water, celestite radiolaria, and strontianite snail shells. Science (Wash., D.C.), 114: 211-213.

Odum, H.T. $1951 b$. The stability of the world strontium cycle. Science (Wash., D.C.), 114: 407-411.

Purton, L.M.A., Shields, G.A., Brasier, M.D., and Grime, G.W. 1999. Metabolism controls $\mathrm{Sr} / \mathrm{Ca}$ ratios in fossil aragonitic mollusks. Geology, 27: 1083-1086.

Radtke, R.L. 1989. Strontium-calcium concentration ratios in fish otoliths as environmental indicators. Comp. Biochem. Physiol. A, 92: 189-193.

Rosenthal, Y., Field, M.P., and Sherrell, R.M. 1999. Precise determination of element/calcium ratios in calcareous samples using sector field inductively coupled plasma mass spectrometry. Anal. Chem. 71: 3248-3253.

Sadovy, Y., and Severin, K.P. 1992. Trace elements in biogenic aragonite: correlation of body growth rate and strontium levels in the otoliths of the white grunt, Haemulon plumieri (Pisces: Haemulidae). Bull. Mar. Sci. 50: 237-257.

Schrag, D.P. 1999. Rapid analysis of high-precision $\mathrm{Sr} / \mathrm{Ca}$ ratios in corals and other marine carbonates. Paleoceanography, 14: 97-102.

Secor, D.H., Henderson-Arzapalo, A., and Piccoli, P.M. 1995. Can otolith microchemistry chart patterns of migration and habitat utilization in anadromous fishes? J. Exp. Mar. Biol. Ecol. 192: 15-33.

Shen, C.C., Lee, T., Chen, C.Y., Wang, C.H., Dai, C.F., and Li, L.A. 1996. The calibration of $D[\mathrm{Sr} / \mathrm{Ca}]$ versus sea surface temperature relationship for Porites corals. Geochim. Cosmochim. Acta, 60: 2849-3858.

Sinclair, D.J., Kinsley, L.P.J., and McCulloch, M.T. 1998. High resolution analysis of trace elements in corals by laser ablation ICP-MS. Geochim. Cosmochim. Acta, 62: 1889-1901.

Smith, S.V., Buddemeier, R.W., Redalje, R.C., and Houck, J.E. 1979. Strontium-calcium thermometry in coral skeletons. Science (Wash., D.C.), 204: 404-407.

Stecher, H.A., III, Krantz, D.E., Lord, C.J., III, Luther, G.W., III, and Bock, K.W. 1996. Profiles of strontium and barium in Mercenaria 
mercenaria and Spisula solidissima shells. Geochim. Cosmochim. Acta, 60: 3445-3456.

Swart, P.K. 1979. The effect of seawater calcium concentrations on the growth and skeletal composition of a Scleractinian coral: Acropora squamosa. J. Sediment. Petrol. 49: 951-954.

Thorrold, S.R., Jones, C.M., and Campana, S.E. 1997. Response of otolith microchemistry to environmental variations experienced by larval and juvenile Atlantic croaker (Micropogonias undulatus). Limnol. Oceanogr. 42: 102-111.

Thorrold, S.R., Campana, S.E., Jones, C.M., and Swart, P.K. 1998. Factors determining $\delta^{13} \mathrm{C}$ and $\delta^{18} \mathrm{O}$ fractionation in aragonitic otoliths of marine fish. Geochim. Cosmochim. Acta, 61: 2909-2919.

Townsend, D.W., Radtke, R.L., Morrison, M.A., and Folsom, S.D. 1989. Recruitment implications of larval herring overwintering distributions in the Gulf of Maine, inferred using a new otolith technique. Mar. Ecol. Prog. Ser. 55: 1-13.

Townsend, D.W., Radtke, R.L., Corwin, S., and Libby, D.A. 1992. Strontium:calcium ratios in juvenile Atlantic herring Clupea harengus L. otoliths as a function of water temperature. J. Exp. Mar. Biol. Ecol. 160: 131-140.

Turekian, K. 1964. The marine geochemistry of strontium. Geochim. Cosmochim. Acta, 28: 1479-1496.

Tzeng, W.N. 1996. Effects of salinity and ontogenetic movements on strontium:calcium ratios in the otoliths of Japanese eel, Anguilla japonica Temminick and Schlegel. J. Exp. Mar. Biol. Ecol. 199: 111-122.

Tzeng, W.N., and Tsai, Y.C. 1994. Changes in otolith microchemistry of the Japanese eel, Anquilla japonica, during its migration from the ocean to the rivers of Taiwan. J. Fish Biol. 45: 671-683.

Vander Putten, E., Dehairs, F., Keppens, E., and Baeyns, W. 2000. High resolution distribution of trace elements in the calcite shell layer of modern Mytilus edulis: environmental and biological controls. Geochim. Cosmochim. Acta, 64: 997-1011

Yoshinaga, J., Nakama, A., Morita, M., and Edmonds, J.S. 2000. Fish otolith reference material for quality assurance of chemical analyses. Mar. Chem. 69: 91-97. 